\section{This old shack}

\author{
by Paul McKellips
}

In 1964, at the ripe old age of five, I was finally deemed sufficiently worldly to watch regular television programs, albeit with strict parental supervision. Of course I was immediately enamored with The Munsters, Gilligan's Island and Batman. But nothing tugged at my wilder side and flair for adventure more than Daniel Boone with Fess Parker.

I'm sure that no animals were harmed in the construction of that awesome raccoon-hide cap or the imitation knockoff that I got for Christmas that year. Set in the 1770s just before and during the American Revolutionary War around Boonesborough, KY, Daniel Boone showcased an iconic family life centered on a log cabin - the detail that captured my vivid imagination the most. Though it may have seemed like an old shack to my doting mother who supervised each episode with me, Daniel Boone's log cabin let me dream of the simple, rural lifestyle, far from the hustle and bustle of city slickers, where a man could raise his young'uns with a beautiful Hollywood actress for a wife, her hair elegantly styled and perfectly in place, while making a rugged living off the land.

Even though times have changed several times since the 1960s, I still have that log cabin dream. And in deference to my late mother, not just any old shack will do this time.

In August of this year, we learned that a different old 'SHAC' might soon be taken down: the 'Stop Huntingdon Animal Cruelty' animal rights campaign. This SHAC claims to have conducted thousands of legal protests against animal research (including almost 800 demonstrations in one year alone) and credits the "relentless and hard-hitting" actions by the Animal Liberation Front (ALF) against suppliers, customers and investors who dared to

McKellips is Executive Vice President of the Foundation for Biomedical Research in Washington, DC. use animals in an effort to find safe and effective medicines.

According to SHAC (http://www.shac. net/), the "innovative combination of SHAC's high profile lawful protest activity and the ALF's unconventional, but highly effective tactics" made their animal rights campaign very successful over the past decade. SHAC's farewell missive even lamented the "courageous freedom fighters (who) have risked breaking the law to commit direct action in the name of animals."

\section{I'd don that old debonair} coonskin cap of mine and stand up for all those who work endlessly to find breakthroughs and cures for the most insidious diseases and conditions imaginable.

Courageous freedom fighters. Like Daniel Boone? Well, that depends on your vantage point: one man's freedom fighter is another man's terrorist. I sometimes wonder if patients with dreadful diseases might view animal researchers who labor tirelessly in search of breakthroughs and cures with little pay and even less gratitude as courageous freedom fighters, too? Maybe like Daniel Boone?

This old SHAC says that its opposition has evolved and that because of the "onslaught of government repression against animal rights activists...it's time to reassess our methods, obstacles and opponent's weaknesses, to build up our solidarity network for activists."

I'm sure that once Daniel Boone was done with his log cabin, that old shack was torn down so a new-and-improved shack could emerge, too.
The new-and-improved SHAC says that even though it is announcing the closure of an old campaign, "it's our knowledge and ability to develop and focus our tactics in the most effective ways, which will continue to make us a threat to the animal exploitation industries."

Now that the Animal Enterprise Terrorism Act has been tested in court and settled as law for years, we've already been privy to the remodeling efforts and tactics that animal rights groups across the world have started to implement: supply chain pressure, ballot initiatives, court challenges, infinite requests under the Freedom of Information Act and public opinion pressure.

If I could find it, I'd don that old debonair coonskin cap of mine and stand up for all those who work endlessly to find breakthroughs and cures for the most insidious diseases and conditions imaginable.

Yes, my log cabin dream remains intact, and I still can't get rid of that little song in my head:

"From the coonskin cap on the top of ol' Dan to the heel of his rawhide shoe

The ripping-est, roaring-est, fightingest man the frontier ever knew

Daniel Boone was a man

Yes, a big man

And he fought for America to make all Americans free

What a goer, what a doer, what a dream-come-true-er was he!"

Even though the old SHAC is gone, Daniel Boone and his log cabin live on in my mind. And it occurs to me that just as they personified my childhood dream, biomedical research professionals might personify the courageous freedom fighters in the dreams of a sick child: the "rippingest, roaring-est, fighting-est" men and women the research frontier has ever seen. 